\title{
Antiinflammatory Activity of Cinnamic Acid Esters
}

\author{
M. E. Godoy, A. Rotelli, L. Pelzer and C. E.Tonn
}

Química Orgánica. INTEQUI-CONICET. UNSL. Chacabuco y Pedernera (5700). San Luis, Argentina E-mail: egodoy@unsl.edu.ar

\begin{abstract}
The cinnamate esters of 3-p-menthanol (trivial name, menthol) (1) and 4(8)-pmenthen-3-ol (trivial name, pulegol) (2) were prepared and their anti-inflammatory activity was measured. Some of the monoterpenoid esters displayed interesting anti-inflammatory activity.
\end{abstract}

\section{Introduction}

Natural phenylpropanes, represented by the bornyl esters of coumaric, caffeic y ferulic acid have shown effectiveness as antiinflammatory drugs [1,2]. Bearing in mind these precedents, in this work we report the results of our tests, by the carregeenan inducededema test method, of the antiinflammatory activity of some cinnamic acid esters prepared in the laboratory.

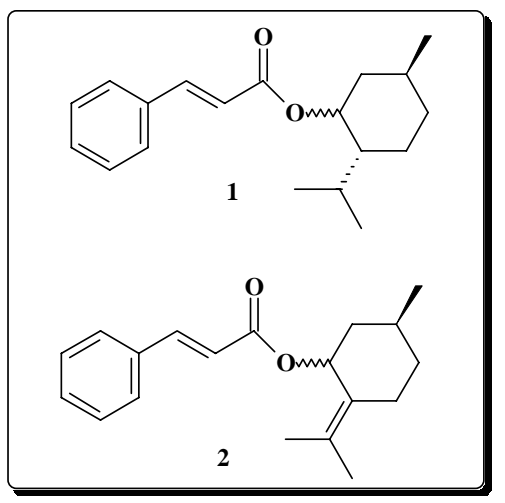

\section{Experimental Part}

\section{Ester Preparation}

Pulegyl and menthyl cinnamates were obtained following the previously describde nmethodology [3]. The corresponding acid chloride was prepared under an inert atmosphere using thionyl chloride in refluxing anhydrous benzene. The acid chloride was added to the monoterpene alcohol dissolved in dry benzene containing a few Mg shavings and then refluxed for $8 \mathrm{hrs}$ [4]. The esters were identified by their physical constants, ${ }^{1} \mathrm{H}$ and ${ }^{13} \mathrm{C}$ NMR and MS. Pulegol was prepared from pulegone by $\mathrm{NaBH}_{4}$ reduction in the presence of $\mathrm{CeCl}_{3}$.

\section{Carrageenan Test}

Acute mouse paw edema was induced by administration of $3.5 \%$ carrageenan. Previously the animals had received an interperitoneal dose of $75 \mathrm{mg} / \mathrm{kg}$ of the compounds under study, while the reference animal received $80 \mathrm{mg} / \mathrm{kg}$ of phenylbutazone. The volumes of the mice paws were compared 1, 3, 
5 , and $7 \mathrm{hrs}$ after administratoion of carregeenan to measure the anti-inflammatory effect $[5,6]$.

\section{Results and Discussion}

All the compounds tested displayed interesting activity although the effects of pulegyl cinnamate were particularly noteworthy (Table 1).

Table 1. Carrageenan Test.

\begin{tabular}{|c|c|c|c|c|}
\hline \multirow{2}{*}{ Products } & \multicolumn{4}{|c|}{ Percentages of Inhibition of Acute Inflam- } \\
\cline { 2 - 5 } & $1 \mathrm{hr}$ & $3 \mathrm{hrs}$ & $5 \mathrm{hrs}$ & $7 \mathrm{hrs}$ \\
\hline Phenylbutazone & $69(\mathrm{i})$ & $73(\mathrm{i})$ & $73(\mathrm{i})$ & $69(\mathrm{i})$ \\
\hline Cinnamic acid & $58(\mathrm{~b})$ & $45(\mathrm{c})$ & $52(\mathrm{~d})$ & 27 \\
\hline Pulegol & $54(\mathrm{~g})$ & $54(\mathrm{~d})$ & $45(\mathrm{e})$ & $47(\mathrm{~g})$ \\
\hline Pulegyl cinnamate & $49(\mathrm{a})$ & $62(\mathrm{j})$ & $56(\mathrm{~h})$ & $50(\mathrm{~b})$ \\
\hline Menthyl cinnamate & $48(\mathrm{f})$ & $49(\mathrm{j})$ & 32 & $47(\mathrm{a})$ \\
\hline
\end{tabular}

(a) $\mathrm{p}<0.002$; (b) $\mathrm{p}<0.0002$; (c) $\mathrm{P}<0.0007$; (d) $\mathrm{p}<0.0001$; (e) $\mathrm{p}<0.003$;

(f) $\mathrm{p}<0.008$; (g) $\mathrm{p}<0.001$; (h) $\mathrm{p}<0.0003$; (i) $\mathrm{p}<0.000001$; (j) $\mathrm{p}<0.00001$.

Acknowledgements: This work was done with funding from CONICET and UNSL. We thanks Dr. P.C. Rossomando and Lic. E. García for the ${ }^{1} \mathrm{H}$ and ${ }^{13} \mathrm{C}$ NMR spectra.

\section{References and Notes}

1. Zschocke, S.; Lehner, M.; Bauer, R. Planta Medica 1997, 63, 203.

2. Maldonado, E; Ramírez Apan, M. T.; Pérez-Castorena, A. L. Planta Medica 1998, 64, 660.

3. Faraoni, M.B. en Tesis de Magister (Univ.Nac.del Sur). «Nuevo método para la síntesis de compuestos organoestánnicos en átomo de estaño quiral» (1997).

4. Gastaminza, A. E.; Ferracutti, N. N. An. Asoc. Quím. Argent. 1983, 71, 587.

5. Sugishita, E.; Amagaya, S.; Ogihara, Y. J. Pharmacobio-Dyn. 1981, 4, 565.

6. Favier, L.S.; Tonn, C.E.; Guerreiro, E.; Rotelli, E.; Pelzer, L. Planta Medica 1998, 64, 657. 